\title{
Effect of Silica Fume on the Properties of Concrete
}

\author{
Ohnmar Zaw \\ Department of Civil Engineering \\ Mandalay Technological University \\ Mandalay, Mandalay Region \\ The Republic of the Union of Myanmar
}

\begin{abstract}
This paper deals with the experimental works on the strength of concrete cube specimens with cement replacement by various percentages $(0 \%$, $5 \%, 7.5 \%$, and $10 \%$ ) of silica fume in concrete mixtures. The use of supplementary cementitious material is gaining much attention owing to its high pozzolanic property and a further improvement in strength properties. Silica-fume is one among the widely used pozzolanic material which exhibits high cementing efficiency due to high silica content. The physical properties of cement with and without silica fume replacement are tested according to ASTM. Mix design calculations for concrete mixtures with $0 \%, 5 \%, 7.5 \%$ and $10 \%$ silica fume content with constant watercement ratio 0.4 are calculated for concrete mixtures according to ACI. The target strength is $34.5 \mathrm{MPa}$. Three concrete cube specimens for each mix are prepared. After 7 days and 28 days, compressive strengths of the mortar and concrete cubes are tested. According to the test results, the concrete mix with $10 \%$ silica fume has the highest compressive strength. Overall, the strength of concrete with various replacement of silica fume enhances greater strength than the normal mix with $0 \%$ replacement.
\end{abstract}

Key Words: Experimental Works, Compressive Strength, Concrete Cube, Silica Fume, Mix Design.

\section{INTRODUCTION}

Concrete is the mostly used material in various types of construction from the flooring to the multi storied high rise structure. It is difficult to point out another material of construction which is as versatile as concrete. In modern concrete technology, adding mineral admixtures to cement is practice in order to improve concrete properties. Silica-fume is a highly reactive material which is used in relatively small amounts to enhance the properties of concrete. It is by-product of producing certain metals in electric furnaces. Silica-fume, also known by other names such as volatilized silica, micro silica, or condensed silica fume, is a by-product of the induction arc furnaces in the silicon metal and ferrosilicon alloy industries. Reduction of quartz to silicon at temperatures up to $2000^{\circ} \mathrm{C}$ produces $\mathrm{SiO}_{2}$ vapors, which oxidize and condensed in low- temperature zone of tiny spherical particles consisting noncrystalline silica. Compared to normal Portland cement and various classes of fly ash, silica-fume samples show particle size distributions finer than 0.1 microns. The material is highly pozzolanic and it increases the water requirement in concrete appreciably unless high range water-reducing admixtures are used. The utilization of waste will produce opportunities for saving energy, time, natural resources and destruction caused in human health. During the production of cement, our natural resources are consumed and carbon dioxide is emitted in the atmosphere. Heat of hydration also leads to increase in temperature of environment and this heat is also responsible for cracks after hardening of concrete. Silica-fume is one among the widely used pozzolanic materials in concrete. It has been used either as a partial replacement for cement or as an additive when special properties are desired. The rapid increase in the use of silica-fume is attributed to its positive effects on the mechanical properties of cementitious composites. The present study is aimed at to evaluate the effect of partial replacement of cement by silica fume on strength properties of concrete for different water to binder ratio

\section{MATERIAL PROPERTIES}

An ordinary Portland cement which has specific gravity of 3.15 is used. Natural river sand having a fineness modulus of 3 and specific gravity of 2.62 is used for cement mortar. Natural river sand having a fineness modulus of 2.19 and specific gravity of 2.62 is used for concrete. The coarse aggregate is locally available lime coarse aggregate passing through $20 \mathrm{~mm}$ sieve opening with specific gravity 2.6 and fineness modulus of 7.17 is used. The chemical composition of Alpha cement is obtained from chemical analysis from Myanmar Conch Co.Ltd. and is shown in Table 1. The chemical composition of silica fume is obtained from chemical analysis from the DSSTRC, Pyin Oo Lwin and is shown in Table 2. 
Table 1. Chemical Composition of Alpha Cement

\begin{tabular}{|c|c|c|}
\hline Chemical constituents & $\begin{array}{c}\text { Composition In } \\
\text { Percentage (\%) }\end{array}$ & $\begin{array}{c}\text { Approximate } \\
\text { Composition Limits of } \\
\text { Portland Cement (\%) }\end{array}$ \\
\hline Silica $\left(\mathrm{SiO}_{\mathbf{2}}\right)$ & 19.99 & $17-25$ \\
\hline Alumina $\left(\mathrm{Al}_{\mathbf{2}} \mathbf{O}_{\mathbf{3}}\right)$ & 4.77 & $3-8$ \\
\hline Ferric Oxide $\left(\mathrm{Fe}_{\mathbf{2}} \mathbf{O}_{\mathbf{3}}\right)$ & 3.87 & $0.5-6.0$ \\
\hline Calcium Oxide $(\mathbf{C a} \mathbf{O})$ & 62.92 & $60-67$ \\
\hline Manganese Oxide $(\mathbf{M g O})$ & 2.78 & $0.1-4.0$ \\
\hline Sulphur Trioxide $\left(\mathbf{S O}_{\mathbf{3}}\right)$ & 2.07 & $1-3$ \\
\hline Others & 1.79 & 2 \\
\hline Loss On Ignition & 1.81 & \\
\hline Total & 100 & \\
\hline CaO/SiO & $3.15(\mathrm{ratio})$ & \\
\hline
\end{tabular}

Table 2. Chemical Composition of Silica Fume

\begin{tabular}{|c|c|}
\hline Chemical Constituents & Composition in Percentage (\%) \\
\hline Silica $\left(\mathrm{SiO}_{\mathbf{2}}\right)$ & 90.21 \\
\hline Calcium Oxide $(\mathbf{C a O})$ & 0.30 \\
\hline Ferric Oxide $\left(\mathrm{Fe}_{\mathbf{2}} \mathbf{O}_{\mathbf{3}}\right)$ & 0.15 \\
\hline Alumina $\left(\mathbf{A l}_{\mathbf{2}} \mathbf{O}_{\mathbf{3}}\right)$ & 0.12 \\
\hline Manganese Oxide $\left(\mathbf{M g O}_{\mathbf{O}}\right)$ & 0.73 \\
\hline Sulphur Trioxide $\left(\mathbf{S O}_{\mathbf{3}}\right)$ & 0.01 \\
\hline Sodium Oxide $\left(\mathbf{N a}_{\mathbf{2}} \mathbf{O}\right)$ & 0.46 \\
\hline Potassium Oxide $\left(\mathbf{K}_{\mathbf{2}} \mathbf{O}\right)$ & 1.51 \\
\hline Others & 6.51 \\
\hline Total & 100 \\
\hline
\end{tabular}

\subsection{Test for Physical Properties of Cement}

The physical properties such as normal consistency, setting time and soundness of cement with $5 \%, 7.5 \%$ and $10 \%$ partial replacement of silica fume are tested according to ASTM. Neat cement paste of a normal consistency is used to determine the initial setting time, the final setting time, and Le Chatelier soundness tests. Therefore, it is necessary to determine the water content which will produce a paste of normal consistency for any given cement. Consistence is determined according to ASTM C 191 by using the Vicat apparatus. This is considered to be normal consistency, when the plunger penetrates the paste to a point 10 $\pm 1 \mathrm{~mm}$ from the top of the mould. The water content of the paste is expressed as a percentage by weight of the dry cement, the usual range of values being between $26 \%$ to $33 \%$. Soundness test is carried out to detect the presence of uncombined lime in cement. This test is performed with the help of Le-Chatelier apparatus. The expansion exhibited by the Le-Chatelier mould should not exceed $1 \mathrm{~mm}$ for any type of Portland cement.

\subsection{Casting of Specimens for Mortar Cubes}

Mortar mixes are prepared to study the compressive strength, at different ages i.e., 7 and 28 days with different percentage of silica-fume. Silica-fume in various percentages ranging from $5 \%, 7.5 \%$ and $10 \%$ by weight of cement is replaced for the total binder content, respectively. For the compressive strength test, water to cement ratio is determined by using the flow table test. Water content for cement is that sufficient to obtain a flow of $110 \pm 5 \%$ in 25 drops of the flow table. Table 3 shows the required amount of materials for cement mortar with various percentage of silica fume. 
Table 3. Required Proportions of Materials (weight in kg) for Cement Mortar

\begin{tabular}{|c|c|c|c|c|}
\hline $\begin{array}{c}\text { Replacement } \\
\text { Percentage }\end{array}$ & $\mathbf{0 \%}$ & $\mathbf{5 \%}$ & $\mathbf{7 . 5 \%}$ & $\mathbf{1 0 \%}$ \\
\hline Cement & 1000 & 950 & 925 & 900 \\
\hline Silica Fume & 0 & 50 & 75 & 100 \\
\hline Sand (SSD) & 2750 & 2750 & 2750 & 2750 \\
\hline Water & 620 & 620 & 630 & 640 \\
\hline Flow Percentages & 107.42 & 107.42 & 107 & 108 \\
\hline Water Cement Ratio & 0.64 & 0.65 & 0.66 & 0.67 \\
\hline
\end{tabular}

For the compressive strength test, the cementitious material to sand ratio is kept at 1:2.75 by weight throughout the study. The compressive strength for mortar with different percentage of silica-fume has been studied at different curing ages, i.e., 7 and 28 days. A mortar mixer machine was used for mixing the dry as well as wet mortar for sufficient time till a uniform mix was achieved. The sizes of the metallic cube mould are two-inch $(50-\mathrm{mm})$ test cubes. The temperature of the air in the vicinity of the mixing slab, the dry materials, moulds, base plates and mixing bowl, shall be maintained between $73.5 \pm 5.5^{\circ} \mathrm{F}$. The temperature of the mixing water, moist closet or moist room, and water in the storage tank shall be set at $73.5 \pm 3.5^{\circ} \mathrm{F}$. The relative humidity of the laboratory shall be not less than 50\%.The compressive mortars are cured one day in the moulds and stripped and immersed in water until tested. The cubes are then tested for 7 days and 28 days. The average of the three cubes is taken as the compressive strength.

\subsection{Casting of Specimens for Concrete Cubes}

The specimens of standard cube of $(150 \mathrm{~mm} \times 150 \mathrm{~mm} \times 150 \mathrm{~mm})$ are used to determine the compressive strength of concrete according to ACI Method. Concrete mixture proportions are prepared for normal mix and with different replacement level $(5 \%$, $7.5 \%, 10 \%$ ) of silica-fume for constant water to binder ratio of 0.4.The target compressive strength is chosen as $34.5 \mathrm{MPa}$. The water content for normal mix and various mix proportions is found to be $205 \mathrm{Kg} / \mathrm{m}^{3}$ without the use of mineral admixtures. The volume of dry rodded coarse aggregate per volume of concrete is taken as 0.68 . The dry rodded unit weight of coarse aggregate is obtained as $1172.15 \mathrm{~kg} / \mathrm{m}^{3}$. Three specimens are tested for $7 \& 28$ days with each proportion of silica fume replacement. The required amount of materials for concrete mixtures with various percentage of silica fumes are shown in Table 4 .

Table 4. Required Proportions of Materials $\left(\mathrm{kg} / \mathrm{m}^{3}\right)$ for Concrete Mixtures

\begin{tabular}{|c|c|c|c|c|}
\hline $\begin{array}{c}\text { Replacement } \\
\text { Percentage }\end{array}$ & $0 \%$ & $5 \%$ & $7.5 \%$ & $10 \%$ \\
\hline Cement & 522.96 & 496.811 & 474.06 & 461.25 \\
\hline Silica Fume & 0 & 26.148 & 38.44 & 51.25 \\
\hline Sand (SSD) & 497.265 & 486.571 & 474.22 & 468.98 \\
\hline Coarse aggregates & 1196.071 & 1196.071 & 1196.071 & 1196.071 \\
\hline Water & 209.184 & 209.184 & 209.184 & 209.184 \\
\hline
\end{tabular}

\section{EXPERIMENTAL TEST RESULTS AND DISCUSSIONS}


Firstly, physical properties of cement, such as setting time and soundness of cement with different replacements of silica fume are tested. Then after 7 days and 28 days, the motor cubes and concrete cubes are tested for compressive strength. Test results are as shown in below.

\subsection{Physical Properties of Cement with Different Replacements of Silica Fume}

The effects of silica fume on the properties of cement are investigated. The physical properties of cement with different percentages of silica fume are shown in Table 5. Consistency of cement depends upon its fineness. Silica fume is having greater fineness than cement and greater surface area so the consistency increases greatly, when silica fume percentage increases. The initial and final setting time of cement increases with the increment of silica fume replacement percentage because of the higher consistency.

Table 5. Physical Properties of Cement with Different Replacements of Silica Fume

\begin{tabular}{|c|c|c|c|c|c|c|}
\hline$\%$ of silica fume & \multicolumn{2}{|c|}{$0 \%$} & $5 \%$ & $7.5 \%$ & $10 \%$ & $\begin{array}{l}\text { ASTM } \\
\text { Range }\end{array}$ \\
\hline Normal Consistency & \multicolumn{2}{|c|}{28.5} & 28.5 & 29.7 & 30.5 & $<10 \%$ \\
\hline Setting time & $\begin{array}{r}\text { Initial } \\
\text { Final }\end{array}$ & $\begin{array}{r}93 \\
143 \\
\end{array}$ & $\begin{array}{c}98 \\
158\end{array}$ & $\begin{array}{l}100 \\
160\end{array}$ & $\begin{array}{l}102 \\
162\end{array}$ & $\begin{array}{l}>45 \text { min } \\
<375 \text { min }\end{array}$ \\
\hline Soundness & \multicolumn{2}{|c|}{0.37} & 0.47 & 0.63 & 0.9 & $<10 \mathrm{~mm}$ \\
\hline
\end{tabular}

\subsection{Compressive Strength of Cement Mortar}

The compressive mortars are cured one day in the moulds and stripped and immersed in water until tested. The cubes are then tested for 7 days and 28 days. The average of the three cubes is taken as the compressive strength.The compressive strengths of cement mortar with different replacements of silica fumes are shown in Table 6 and in Figure 1. The maximum compressive strength is $24.49 \mathrm{MPa}$ and $33.09 \mathrm{MPa}$ at 7 and 28 days. The maximum compressive strength is observed at $10 \%$ replacement of silica fume.

Table 6. Compressive Strengths of Mortar with Different Replacements of Silica Fume

\begin{tabular}{|c|c|c|}
\hline Silica fume $\%$ & 7Days(MPa) & 28Days(MPa) \\
\hline 0 & 21.58 & 32.37 \\
\hline 5 & 21.82 & 32.84 \\
\hline 7.5 & 22.54 & 33.09 \\
\hline 10 & 24.49 & \\
\hline
\end{tabular}

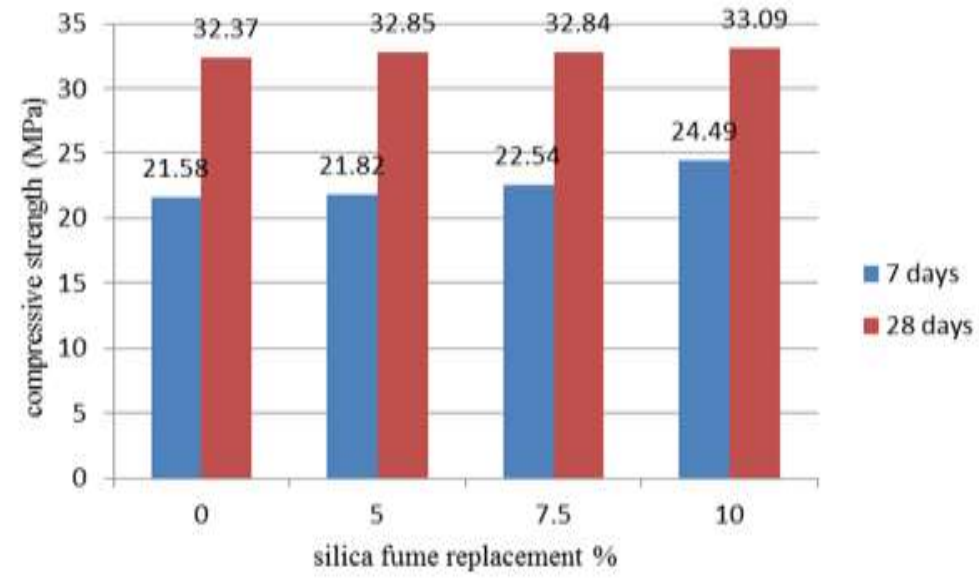

Figure 1. Comparison of compressive strength of mortar with different proportions of silica fume

\subsection{Compressive Strength of Concrete}


The properties of fresh concrete and 7 days and 28 days compressive strengths of concrete cubes are also investigated. Fresh concrete containing silica-fume is more cohesive and less prone to segregation. The air content of concrete also increases with increment of silica fume replacement. The compressive strength test results of concrete cubes are shown in Table 7 and Figure 2.

Table 7. Compressive Strengths of Concrete with Different Replacements of Silica Fume

\begin{tabular}{|c|c|c|}
\hline Silica fume\% & 7Days(MPa) & 28Days(MPa) \\
\hline $\mathbf{0}$ & 30.01 & 41.84 \\
\hline $\mathbf{5}$ & 30.32 & 42.32 \\
\hline $\mathbf{7 . 5}$ & 32.01 & 42.31 \\
\hline $\mathbf{1 0}$ & 35.90 & 43.31 \\
\hline
\end{tabular}

For normal mix, compressive strengths of concrete are $30.01 \mathrm{MPa}$ and $41.84 \mathrm{MPa}$ respectively. The maximum compressive strengths are $35.9 \mathrm{MPa}$ and $43.28 \mathrm{MPa}$ for 7 days and 28 days at $10 \%$ replacement of silica fume. There is a significant improvement in the compressive strength of concrete because of the high pozzolanic nature of the silica fume and its void filling ability.

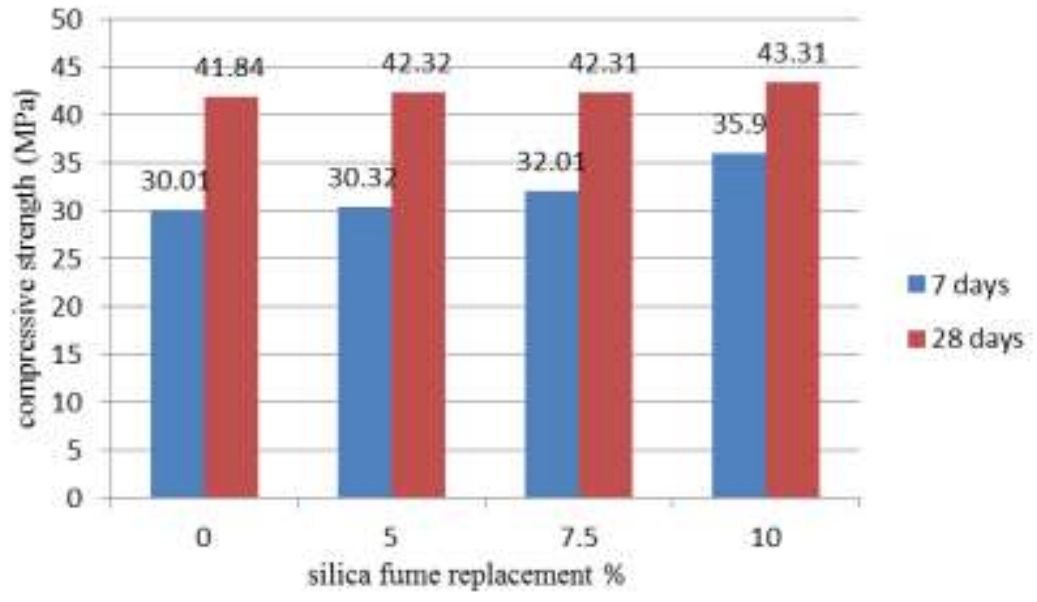

Figure 2. Comparison of compressive strength of concrete with different proportions of silica fume

\section{CONCLUSIONS}

The normal consistency and setting time of cement increases with the increment of silica fume content. The workability and cohesion of concrete improve with addition of silica fume.The compressive strength increases with increase in silica fume content for both mortar and concrete due to the pozzolanic action and binder formation of silica fume and cement. There is a gradual increased in strength with increase in silica fume content. The different replacement mixes of compressive strengths are greater than the normal mix. The maximum values of compressive strength for mortar are $41.84 \mathrm{MPa}$ and for concrete, $43.31 \mathrm{MPa}$ at $10 \%$ replacement of silica fume for 28 days. So, the optimum replacement level of silica fume is found as $10 \%$.

\section{REFERENCES}

[1].Dr.Sounthararajan V.M, "Micro Filler Effects of Silica Fume on the Setting and Hardening Properties of Concrete", Article in Research Journal of Applied Sciences, Engineering and Technology, August 2013.

[2]. Venkatesh Babu DL, Nateshan SC. Investigations on silica fume concrete, The Indian concrete Journal, September 2004, pp. 57-60.

[3]. Bayasi, Zing, Zhou, Jing, (1993) “Properties of Silica Fume Concrete and Mortar”, ACI Materials Journal 90 (4) 349 - 356.

[4].Khedr, S. A., Abou - Zeid, M. N., (1994) "Characteristics of Silica-Fume Concrete”, Journal of Materials in Civil Engineering, ASCE 6 (3) 357 - 375.

[5] ASTM C 109-02, Standard Test Method for Compressive Strength of Hydraulic Cement Mortars 
International Journal of Engineering Research And Advanced Technology, Vol.5, Issue 8, August-2019

[6] Engineered Concrete, Mix Design and Test Methods. 